\title{
Analysis Of Mathematical And Disposition Creative Thinking Ability Of Students Through Learning Alternative Solution Worksheet
}

\author{
$1^{\text {st }}$ Ratni Purwasih ${ }^{1}, 2^{\text {nd }}$ Rippi Maya ${ }^{2}, 3^{\text {st }}$ Luvy Sylviana Zanthy ${ }^{3}, 4^{\text {st }}$ Eva Dwi Minarti \\ $\left\{\underline{\text { ratnipurwasih61@gmail.com }}{ }^{1}, \underline{\text { rippimaya @ gmail.com }}{ }^{2}, \underline{\text { lszanthy@ gmail.com }}{ }^{3}\right.$,eva.arti@ yahoo.co.id $\left.{ }^{4}\right\}$
}

IKIP Siliwangi, Jl. Terusan Jenderal Sudirman, Cimahi City in Indonesian 1,2

\begin{abstract}
One of the important problems in learning mathematics is creative thinking. In some elementary or secondary schools, teachers still lack the facilitation of students to develop creative thinking skills. The solution to the problem is that it requires learning innovation to convey mathematical concepts so that students can practice and stimulate mathematical thinking skills. The objectives that have been studied are analyzing students' creative thinking abilities and dispositions through alternative solution worksheet learning. The disposition referred to in this study is a strong attitude of desire, awareness, interest, and sincerity in learning mathematics, as well as an appreciation of mathematics and applications in other fields. The research stages that have been carried out are designing learning activities through alternative solution worksheet learning to familiarize students with open-ended questions; give a test of the ability to think creatively, choose a research subject and provide a mathematical disposition questionnaire. The results of the research that had been carried out were students categorized as high-ability $(33.33 \%), 10$ students with moderate abilities (27.77\%), and 14 low-ability students (38.88\%). Learning that has used the Alternative Solution Worksheet approach makes students more active, more creative, independent, and more motivate.
\end{abstract}

Keywords: Mathematical Creative Thinking Ability, Disposition, Alternative Solution Worksheet Learning

\section{Introduction}

The ability to think creatively is the ability of a person to create something new, both ideas and real works that are relatively different from those that have existed before. Students' creative thinking ability cannot develop well if the learning process is in class, the teacher does not actively involve students, does not provide opportunities for students to build basic concepts and ways of teaching teachers in schools still conventionally [1]. It is very important that learning can help students to develop their creativity. Because creativity is a skill that can be learned. Facts on the ground show that students' mathematical creative thinking skills are still low. Creativity is the ability of a person to produce any composition, product, or idea that is basically new, and before that no one has created [2]. Creativity is a condition, attitude, or condition that has a special nature and can hardly be formulated completely. During this time, the purpose of mathematics learning is that 
students can master the material or mathematical concepts that have emphasized mathematical procedures so that students' ability is to memorize formulas. Another factor that causes unsuccessful learning in mathematics is low activity and confidence. The definition of creativity as condition that affects each other between the abilities and processes produced by individuals or groups, which are new (novel) and useful in social life [3]. According to Sariningsih and Purwasih that the affective domain is one of the factors that determine learning success [4].

When learning in class, the teacher dominates and the source of learning is centered on the teacher. Teachers are more active while students tend to be passive. This has made learning in the classroom boring and lackluster. When the process of learning mathematics has taken place in the classroom, the teacher finds some obstacles. High school students who have varied attitudes and characters and unstable emotions make it difficult for teachers to provide teaching. One of the factors of the weakness of high school students in learning mathematics is the teacher do not provide opportunities for students to develop their mathematical abilities, especially creative thinking. Creative thinking is rarely emphasized in mathematics learning because mathematics learning that has been implemented is oriented towards the development of analytical thinking with routine problems [5]. Therefore, learning mathematics in schools requires innovation in the delivery of material aimed at students to practice and develop their mathematical thinking skills. Students can practice independently and develop the ability to think creatively through learning that is comfortable and meaningful. alternative learning worksheet solutin one of the learning processes that helps students to improve creative thinking skills. one of the affective aspects that can help the creative thinking process of students is a mathematical disposition. Mathematical disposition is one of the responses of a person how to think and act mathematically in a positive way. Disposition is a tendency to behave consciously (consciously), regularly (frequently), and voluntary (voluntary) to achieve certain goals[6]. The disposition referred to in this study is a strong attitude of desire, awareness, interest, and sincerity in learning mathematics, as well as an appreciation of mathematics and applications in other fields. The ASW-based student worksheet is a student worksheet that helps students to answer a question with more than one answer. ASW-based worksheets can encourage student involvement with alternative solutions to mathematical problems during learning. This ASW-based worksheet contains open-ended questions.

Mathematics learning through ASW-based worksheets can help students think creatively through open ended questions and students can answer various questions. Through Alternative Solutions Worksheet instructional materials as well, students have the opportunity to explore their abilities through open ended questions, the relationship between knowledge they get with everyday life and practice the creative thinking process. Worksheet alternative solutions (ASW) is a student worksheet that helps students to answer questions or questions through a thought process to answer these questions with many correct answers. ASW provides opportunities for students to answer initial questions and solutions (the first solution found) and alternative solutions (other solutions found after the first solution) [7].In ASW the questions used are open-ended problems. Students exploring ideas to give answers to open ended questions are expected to cause curiosity. in addition, students have a flexible attitude toward mathematical ideas that are formed, self-confidence, can apply mathematics to other situations in everyday experience, and understand the role of mathematics in everyday life. These processes are part of a mathematical disposition, so that through this ASW-based learning process is expected to improve students' mathematical disposition abilities.

Indicators of creative thinking abilities are: (1) Current thinking (fluency) which includes finding many ideas, answers, or problem solving; (2) flexible thinking is the ability to produce varied ideas, (3) original thinking which includes being able to make unusual combinations of parts or elements; (4) elaboration thinking (elaboration) which includes being able to enrich and 
develop an idea or product [8]. Whereas the disposition referred to in this study is a strong attitude of desire, awareness, interest, and sincerity in learning mathematics, as well as an appreciation of mathematics and applications in other fields. The purpose of this research is to see how far the ability of creative thinking and mathematical disposition of high school students through learning Alternative

Solution

Worksheet.

\section{Method}

\subsection{Research Procedurs}

The approach used in this study is a qualitative approach with descriptive methods. Descriptive method is a method used to describe or analyze a research result but is not used to make broader conclusions [9]. This study describes or analyzes students' creative thinking abilities and mathematical dispositions.

\subsection{Subjects and Research Locations}

The population in this study were all high school students in class $\mathrm{X}$ in the city of Cimahi. The sample of this study was the $\mathrm{X}$ grade students in one of the high schools in Cimahi. This research instrument is a test of mathematical creative thinking skills in essays and mathematical disposition questionnaires. The form of the disposition scale used in the study is a modified Likert model scale. Data analysis techniques were carried out through data reduction, followed by data presentation, and drawing conclusions and verification.

\section{Result and Discussion}

This research was carried out to high school students of class X as much as one class. Researchers collected data through tests of creative thinking abilities and questionnaires on mathematical dispositions. Alternative solution worksheet learning has been carried out before students carry out tests about the ability to think creatively. This ASW learning has been held for four meetings in the class. The main material delivered through ASW is the eskponen and the root form. Analysis of the mathematical creative thinking process of students is categorized into 3 levels: students who have high, medium and low creative thinking abilities. The researcher analyzed the results of all students who had worked on the creative thinking problem.

\subsection{Result}

Indicators of creative thinking abilities include fluency, flexibility, originality, and elaboration. The results of the students' mathematical creative thinking skills based on these indicators are: The maximum score of each item for the ability to think creatively is five. The average of the fluency indicator is 4.11 by $82.2 \%$, flexibility is 4.33 by $86.6 \%$, originality is 3.38 by $67.7 \%$ and elaboration is 4.22 by $80.23 \%$. Student scores can be seen in the following table.

Table 1. Indicator of Creative Thinking Ability

\begin{tabular}{|c|c|c|c|c|c|}
\hline \multirow[t]{2}{*}{ No } & \multirow[t]{2}{*}{ Indicator } & \multirow[t]{2}{*}{ SMI } & \multicolumn{3}{|c|}{ Aspect } \\
\hline & & & Score & $X$ & $\%$ \\
\hline 1 & Fluency & 5 & 148 & 4.11 & 82.2 \\
\hline 2 & Flexibility & 5 & 156 & 4.33 & 86.6 \\
\hline 3 & Originality & 5 & 112 & 3.38 & 67.7 \\
\hline
\end{tabular}




\begin{tabular}{|l|l|c|c|c|c|}
\hline 4 & Elaboration & 5 & 152 & 4.22 & 80.23 \\
\hline 5 & Total average & 20 & 568 & 4.01 & 80.23 \\
\hline
\end{tabular}

The table above shows the results of students' mathematical creative thinking skills. The table above shows the average results of the overall student score. Flexibility indicator number two has the highest average score and percentage. The problem at number two has given students the opportunity to think in producing ideas or ideas that vary from different perspectives to each other in solving problems. While the average score and the lowest percentage are in the originality indicator. Findings obtained during the study, students are difficult to process their cognitive abilities to produce a new idea and the idea does not exist before. Students have not been able to answer questions in unique and unusual ways. Below are examples of questions and answers for students who have originality indicators.

Suppose you are asked to calculate the unit number from 72017. How do you solve the problem in the most effective way possible without the help of assistive devices such as calibers etc. Give at least three ways to resolve the problem!

Fig. 1 The Originality Indicator's Creative Thinking Ability Ability

Students who are in the category of high creative thinking are students who can estimate solutions, draw up plans, and solve these problems based on plans that have been prepared previously. Renewal in answering questions is a key characteristic of someone being creative [10]. Seen in Figure 2 which showa one of the high category student answer.
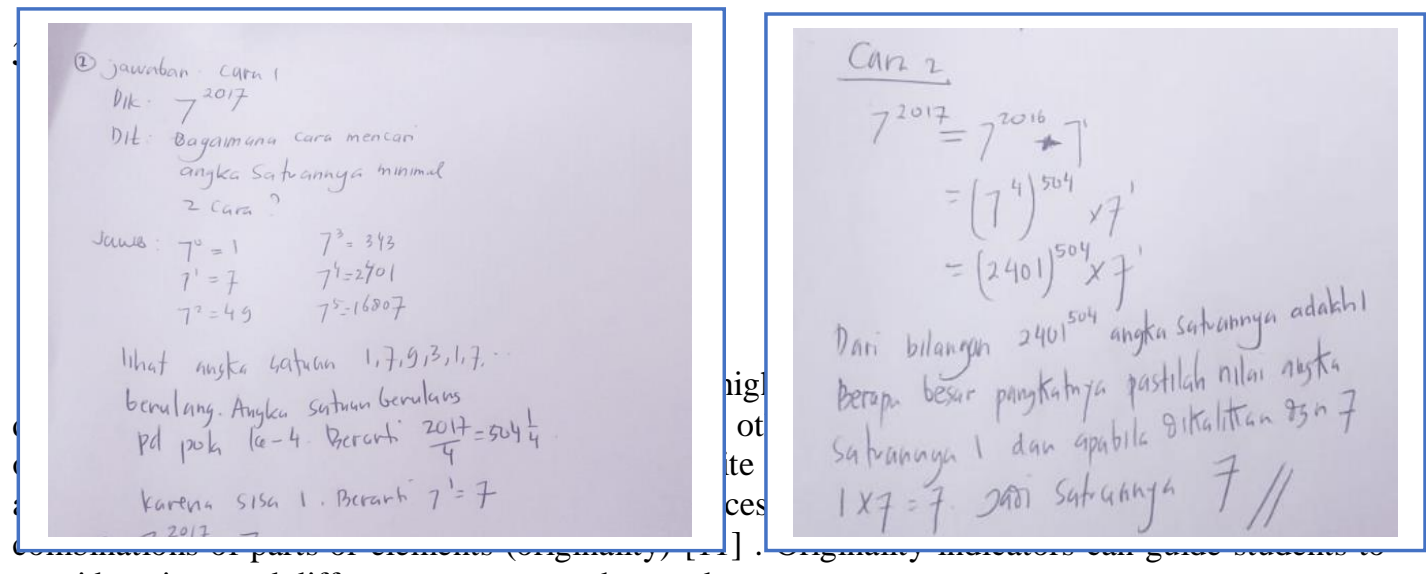

1 Fig.2. Student Work Results in the Categorv of Creative Thinking Abilitv High Level 


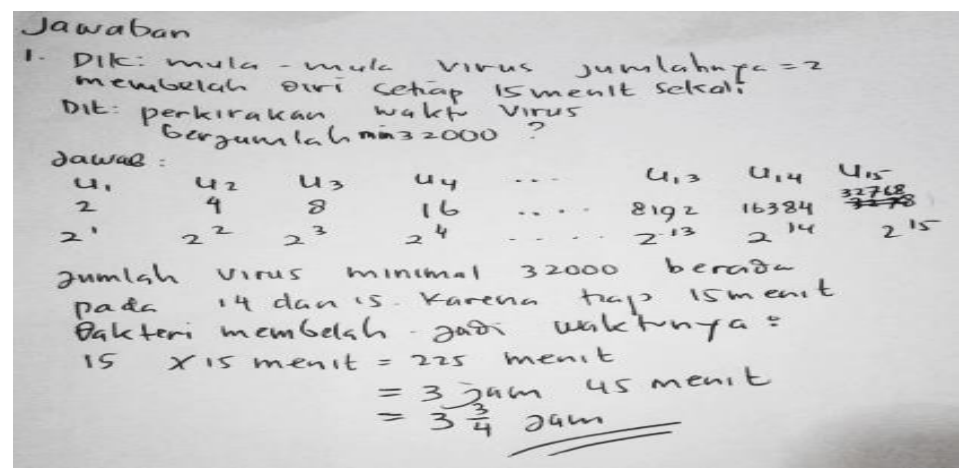

Fig. 3. Students' Work Outcomes of Medium Creative Thinking Ability

From Figure 3. Students capable of level creative thinking are able to understand the problem and plan the completion of mathematical problems as planned. However, the student has the character of giving up easily when experiencing difficulties. Students answer questions according to the procedure and the response is the same as other students. Students have understood the algebraic calculation process well. These students also look systematic and structured in completing their work. Students already have the ability to complete and issue ideas or ideas correctly. The characteristics of these students are in accordance with the indicators of creative thinking, namely fluency.

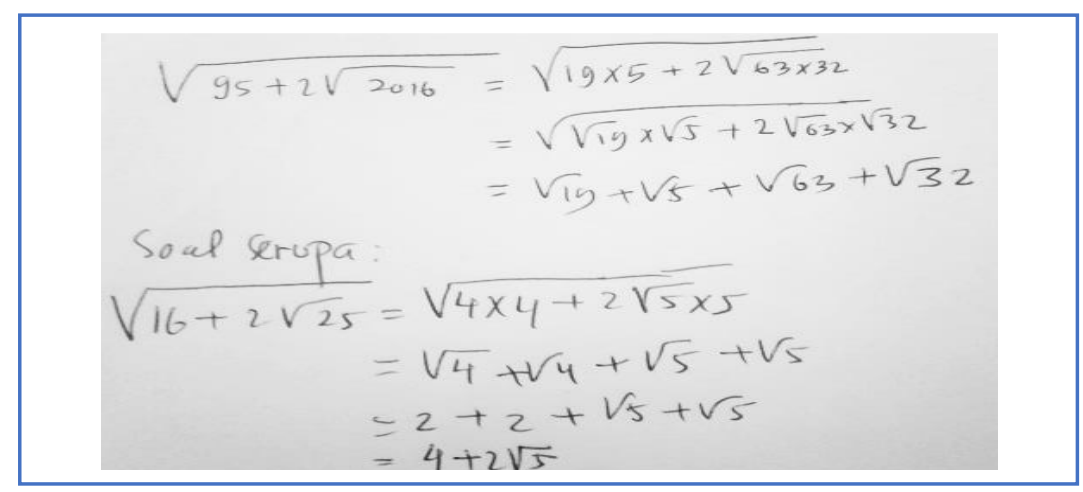

Fig.5. Students' Work Results of Low Creative Thinking Ability

From Figure 5. Students with low category creative thinking are difficult to understand problems. Even easy problems they don't have ideas or ideas for planning solutions. They have not been able to identify the plan to resolve the problem correctly or not. The basic calculation of the algebra is not correct. The response to mathematical problems is less varied, the answers to questions are incomplete and still wrong, and have not been able to describe the problem correctly.

\subsection{Discussion}

Students who have solved the problem of creative thinking ability still have difficulties in the originality indicator. Students have difficulty designing solutions that have not been taught by the 
teacher before. Students have not been able to give answers to more than one correct answer. In general, students have not been able to complete and work on the problem of creative and complete thinking skills. From the results of students' ability analysis, there are some students who have given one answer and are wrong. Students who are capable of high-level creative thinking have special skills in solving problems. The student responds to math problems from different points of view. The skills to solve this math problem are not all students have. Student skills are also something that we need to learn deeply [11]. Students' creative thinking ability cannot only be described only by giving a level to the response given without looking from another perspective.

Some answers are said to be diverse if the answers from students appear to differ and follow certain patterns [12]. Research carried out by previous researchers that compiled around 210 studies on creative thinking abilities shows that one of the factors that support the development of creative thinking abilities is the use of certain learning approaches accompanied by the autonomy of students to a certain level [13]. Siswono said that there was a relationship between problem solving with the ability to think creatively because creative thinking is a process that is used when bringing (bringing up) a new idea by combining ideas previously carried out[14].

In general, the analysis of students' mathematical disposition ability through Alternative Solution Worksheet shows a positive attitude. This means that with the Alternative Solution Learning Worksheet provides a new color in the student learning process. Students have felt happy and comfortable with learning based on the Alternative Solution Worksheet. The attitude that has emerged in these students, helps students to learn and students want to get good learning outcomes. The findings of the study, there is a positive correlation between students' good disposition ability and creative thinking ability. One of the factors of student learning difficulties is the weak affective ability possessed by students [15]. Students who have strong perseverance and discipline skills are able to achieve good learning achievement. This attitude is part of a mathematical disposition that must be developed within the student itself. The important thing is also mental abilities or academic abilities such as fluency in reading problem solving problems that have many ways students must have a solution. This is a process of self-direction to transform the basic abilities of students towards higher academic skills or high order thinking mathematics[16]. Pembelajaan alternative solution worksheet memberikan kesempatan siswa untuk melatih kemampuan berpikir kreatif melalui soal open ended [7].

Based on the results of research by experts that ASW increases learning motivation, students' self-confidence, and the role of teachers in the classroom. The role of the teacher is very important in learning because it determines whether students succeed or not in the learning process. Nickson revealed that in mathematics learning, the teacher is tasked to help students build mathematical concepts with their own abilities through an internalization process so that the concept is rebuilt through information transformation with prior knowledge so as to form new concepts[18]. This alternative solution worksheet learning helps students to increase their creative thinking process to solve open ended problems. Creativity in mathematics is more about students' creative thinking skills in solving open questions. Because in general most of the activities carried out by someone who studies mathematics are thinking. Some experts say that creative thinking in mathematics is a combination of logical thinking and divergent thinking based on intuition but in awareness that takes into account flexibility, fluency and novelty[19]. Students who have different abilities will have different creative abilities [20]. Students are categorized as having fluency in thinking if they are able to solve problems at least using two ways to answer the questions correctly. Students who have high ability of fluency and flexibility in thinking and show newness of thinking are included in the criteria of high level of creative thinking ability. Students have fluency in thinking skills, but do not have the flexibility and novelty of thinking so that they fall within the criteria of the level of medium-level creative thinking skills. ASW learning encourages students to 
be active and diligent, trying to optimally issue ideas to work on math problems.

\section{Acknowledgment}

Thank you to the school of SMA 1 Ngamprah for facilitating us to conduct research in the 20172018 academic year.

\section{References}

[1] H. Sugilar, "Meningkatkan Kemampuan Berpikir Kreatif Dan Disposisi Matematik Siswa Madrasah Tsanawiyah Melalui Pembelajaran Generatif “Jurnal Infinity,vol. 2, no 2, pp. 156-168, 2013.

[2] E. B. Hurlock, “ Perkembangan Anak,” Erlangga., Jakarta, 1978.

[3] J. Sheffield, “ Creating and developing promising young mathematicians. Teaching Children Mathematics," vol. 6 no.7, pp. 416-419,2000.

[4] R, Sariningsih and R. Purwasih, "The relationships among pre-service mathematics teachers' beliefs about mathematics, mathematics teaching, and use of technology in China," Eurasia J. Math. Sci. Technol. Educ., vol. 11, no. 6, pp. 1363-1378, 2015.

[5] T.Y.E. Siswono, "Model pembelajaran matematika berbasis pengajuan dan pemecahan masalah untuk meningkatkan kemampuan berpikir kreatif,"Surabaya: Unesa University.

[6] A. Mahmudi, "Tinjauan Asosiasi antara Kemampuan Pemecahan Masalah Matematis dan Disposisi Matematis",Disajikan pada Seminar Nasional Pendidikan UNY, 17 April 2010. Yogyakarta: FMIPA UNY.

[7] S.Y. Lee, "The Effect Of Alternative Solutions On Problem Solving Performance", (Online).http://www.cimt.plymouth.ac.uk/journal/lee.pdf (diakses pada 29/11/2012 ).

[8] P. Wu and W. Chiou, "Postformal thinking and creativity among late adolescents: A postpiagetian approach. Adolescence", vol. 43 no.17, pp. 237-251, 2008.

[9] Sugiyono, “Metode Penelitian Kuantitatif, Kualitatif, dan R\&D”,Bandung: Alfabeta,2017.

[10] M.F. Amir., M.D. Kusuma, and Wardana, "Pengembangan Domino Pecahan Berbasis Open Ended Untuk Meningkatkan Kemampuan Berpikir Kreatif Siswa SD," Aksioma Jurnal Pendidikan Matematika FKIP Univ. Muhammadiyah Metro, vol. 6,no. 2,pp. 178-188,2017.

[11] D.K. Faridah, "Analisis Proses dan Kemampuan Berpikir Kreatif Siswa dalam Matematika Melalui Tugas Open-Ended ”, Jurnal Kreano, vol. 3, no. 2,pp. 2-7, 2012.

[12] A.A. Saefudin, "Pengembangan Kemampuan Berpikir Kreatif Siswa Dalam Pembelajaran Matematika Dengan Pendekatan Pendidikan Matematika Realistik Indonesia (PMRI)," Al-Bidāyah, vol. 4,no. 1, pp. 37-48,2012.

[13] D. Davies, D., D. Jindal-Snape., C. Collier., R. Digby., P. Hay., and A. Howe, "Thinking Skills and Creativity ," vol. 8, pp. 80-91, 2013.

[14] T. Utomo., D. Wahyuni., and S. Hariyadi, "Pengaruh Model Pembelajaran Berbasis Masalah (Problem Based Learning) Terhadap Pemahaman Konsep dan Kemampuan Berpikir Kreatif Siswa (Siswa Kelas VIII Semester Gasal SMPN 1 Sumbermalang Kabupaten Situbondo Tahun Ajaran 2012/2013) ,"Jurnal Edukasi Unej, vol. 1, no. 1, pp. 5-9, 2014. 
[15] R. Purwasih, and R. Sariningsih, "Pembelajaran Berbasis Masalah untuk Meningkatkan Kemampuan Berpikir Kreatif dan Self-Concept Siswa SMP, "Jurnal Didaktik Matematika, vol. 4, no. 1, pp. 15-24, 2017.

[16] R. Purwasih , Peningkatan Kemandirian Belajar Mahasiswa Melalui Pembelajaran Personalized System Of Instruction, "Seminar Nasional Matematika dan Pendidikan Matematika STKIP Siliwangi, vol.4, no. 1,pp. 187-196, 2016.

[17] A.Y. Jamiah, and Bistari, "Penerapan Pembelajaran Kooperatif Berbantuan Alternative Solutionss Worksheet untuk Meningkatkan Kemampuan Pemecahan Masalah Matematis Siswa," Jurnal Pendidikan dan Pembelajaran, Pontianak : Universitas Tanjungpura, 2015.

[18] M. Syaban, "Menumbuhkembangkan Daya dan Disposisi Matematis Siswa Sekolah Menengah Atas Melalui Pembelajaran Investigasi, ”Educationst, vol 2, no. 2,pp. 129-136, 2011.

[19] E.A. Silver, E.A, "Fostering Creativity through Instruction Rich in Mathematical Problem Solving and Problem Posing," vol. 29, no. 3, 1997, Tersedia: http://www.fizkarlsruhe.de/fiz/publica tions/zdm/2dm97343.pdf (23 maret 2018).

[20] W. Murtafiah, "Profil Kemampuan Berpikir Kreatif Mahasiswa Dalam Mengajukan Masalah Persamaan Diferensial, ” Jurnal Ilmiah Pendidikan Matematika, vol. 5, no.2, pp. 73-81,2017. 